\title{
A Sexual Ritual with Māyā in Matsyendrasaṃhitā 40
}

\author{
Csaba Kiss
}

\section{Introduction}

In this short article I revisit the Matsyendrasaṃhitā (hereafter MaSaṃ), a Kubjikā-Tripurā oriented tantric yoga text of the Ṣaḍanvayaśāmbhava tradition, probably from thirteenth-century South India, core chapters of which I edited and translated for my PhD studies under the supervision of Professor Alexis Sanderson. My purpose there was to demonstrate that this text provides evidence for a transitional phase in the history of Śaiva Tantra, revealing aspects of a transition from Kaula practices to early Hațhayoga. In the present essay I analyse, and partly edit, MaSam chapter 40, in which a unique and somewhat ambiguous variant of a Śrīvidyā-type sexual ritual is described, and which Professor Sanderson was kind enough to read with me in Oxford in 2005. I would like to dedicate this paper to him, offering new interpretations of some key elements, and thus updating my previous analysis (Kiss 2009, 66). ${ }^{1}$

My approach is based on textual criticism: by restoring the text using four available manuscripts, I aim at giving an accurate translation and interpretation, which then enables me to draw some modest conclusions regarding the history of Śaivism around the thirteenth century. ${ }^{2}$ I would like to contribute to the contemporary research on Śaiva sexual rituals which focuses on their religio-historical importance. For although it is now generally acknowledged that sexual rituals are a distinctive feature of some of the Saiva tantric tradi-

1 On the Șaḍanvayaśāmbhava tradition, see Sanderson 1988, 687; 2002, 2-3; 2014, 72-73, 76-77, 8o. On details concerning the MaSam, see Sanderson 2014, 8o, Kiss 2007, 2009, 2011, and 2020 (forthcoming). All quotations from the MaSam are either from Kiss 2020 (forthcoming) or from my draft edition of the text.

2 I would definitely like to steer clear of some of the nineteenth- and twentieth-century, and contemporary approaches to the topic of tantric sexual rituals, which include, as White observes (2000, 4-5): (1) denial, (2) emphasis on the philosophical reinterpretation of these rites, "while generally denying the foundational importance of transgressivity or sexuality to the traditions themselves," and (3) the commodification of New Age "Tantric Sex" as a commercial product. 
tions, much work remains to be done on this topic. ${ }^{3}$ Alongside Sanderson's findings in many of his publications, ${ }^{4}$ as well as publications by Dupuche (2003), White (2003) and Biernacki (2007), Hatley's work, especially on the asidhärăvrata (Hatley 2018, 195-215), a sexual ritual attested in the Picumata/Brahmayāmala (BraYā), chapter 40, as well as in the Niśvāsatattvasaṃhitā and the Matangapārameśvara, is fundamental and is a source of inspiration and in many respects a model for this essay. Mallinson's exploration of the hathayogic techniques of khecarimudrā, vajroli and amarolì is closely related to this field of research (Mallinson 2007, 221-223, notes 333-334 and 336-337). My own contribution so far (Kiss 2015) comprises an analysis of the BraYā's relevant teachings in BraYā 45 on sexual encounters that involve the gathering and magical use of sexual fluids.

A detailed overview of the types of sexual ritual found in tantric and hathayogic texts is beyond the scope of this short essay, ${ }^{5}$ but a number of their distinctive features can be listed here. This list mainly concerns the variable nature of the female and male partners, and the nature of the sexual act. Note that categorisation of a phenomenon like this is greatly complicated by that fact that many features overlap:

(1) sexual rituals involving restraint or celibacy; 6

(2) a sexual act at the end of which the practitioner applies the vajrolimu$d r \bar{a}$, "the practice of urethral suction [...] to draw up the combined sexual fluids";

(3) sexual rituals producing male and female sexual fluids, which are then used and consumed for magical purposes; 8

(4) sexual rituals with one's own wife/partner vs. other partners; ${ }^{9}$

3 As Shaman Hatley also remarks (2018, 195-196).

4 E.g. Sanderson 2005a, 110-114, note 63; 2007, 284-287; 2009, 132 ff., 294, note 699; and 2014, 57.

5 See a similarly non-comprehensive but more detailed list of types of tantric sexual rituals in Hatley 2018, 196-199.

6 E.g. the asidhāravrata, "Razor's Edge Observance," as taught in BraYā 40, which involves sexual contact with a beautiful woman without the sādhaka's engaging in orgasm. (See Hatley 2018, 195-215.) See also BraYã 45.270-296ab, in which a sexual ritual involving "restraint" (avagraha) is taught (Kiss 2015, 49).

7 See Mallinson $(2007,189$ note 149). Vajroli is described e.g. in the Vaiṣnava Dattātreyayogaśa stra, vv. 299-314.

8 E.g. BraYā 45, where several variants of a basic type of sexual ritual are described (see Kiss 2015).

9 See for example BraYā $24.32 \mathrm{~cd}$, where one's mother, sister, daughter and wife are listed as possible partners (figuratively or otherwise): mātā ca bhaginī putrī bhāryā vai dūtayah smṛtā [h] . See also Jayaratha ad Tantrāloka 29.102 addressing the question after citing the line svapatni bhaginìmātā duhitā vā śubhā sakhī: ityādyuktyā svapatny apiatra kasmāt na parigaṇitā ... ("In 
(5) sexual rituals with one partner vs. several partners; ${ }^{10}$

(6) sexual encounters with human or visionary Yoginīs, or other divine beings; ${ }^{11}$

(7) highly æstheticized, philosophic descriptions of Śaiva sexual rituals; ${ }^{12}$

(8) sexual rituals involving the visualisation of a goddess or the mental projection of the image of a goddess onto the female partner, ${ }^{13}$ and so forth. ${ }^{14}$ The passages from MaSam 40 analyzed and presented below seem to represent a variety of the last type listed above, but they are somewhat ambivalent: after mentioning sexual encounters with (human) Yoginīs (verses 38 and 40-41), the text focuses on a somewhat ambiguous sexual ritual which could be read either as involving an exclusively visualised goddess as partner or as prescribing the projection of an image of the goddess onto a human sexual partner. It also teaches the magical use of male sexual fluid (real or imaginary). MaSam 40 is somewhat ambiguous in other aspects as well, and it seems that it is through the analysis of this ambiguity that we may gather clues concerning the history of late Śaiva traditions and the transition between Śaiva Tantra and early Haṭhayoga.

\section{$2 \quad$ Details and Ambiguities}

The beginning of the chapter in question, MaSam 40.1-28, stands somewhat apart from the rest of the chapter and does not discuss sexual rituals. Nevertheless, a short analysis of it may be useful here. The text starts (1-6ab) with the proclamation of its topic: the rituals of Kula/Kaula conduct (kulācāravidhi) characterised by "the great non-dualist practice" (mahādvaita) and "freedom

these kind of statements, why is one's own wife not enumerated?") See also Dupuche 2003, $249 \mathrm{ff}$.

10 E.g. BraYā $45.574 \mathrm{~cd}-557 \mathrm{ab}$, where sexual rituals with four to eight women are taught. See also Jayadrathayāmala, Șațka 4, National Archives, Kathmandu, Ms 1-1468, ff. 206v3207v5 and Kșemarāja's Daśāvatāracarita 10.26. For these references, see Sanderson 2007, 284-287; and 2009, 294 note 699.

11 E.g. the sādhaka engages in "great amusement" with Nāga girls and Āsurīs (demonesses) in BraYā 59.107cd (f. 254r): nāgakanyais mahākrị̄̂ā āsurībhiś ca jāyate.

12 E.g. Tantrāloka 29 (see Dupuche 2003).

13 E.g. Nityotsava, p. 6o: atha tām devarūpām vibhārya ... ("And visualising her [the sexual partner] in a godly form ...").

14 This list could easily be expanded by using more variables, as Shaman Hatley has suggested (personal communication): partners; place/space/circumstances; roles of mantra, visualization, accoutrements; kinds of meaning given to the practice; aims/goals; fluids; etc. 
from conventional practices" (nirācāra), both familiar terms from earlier Śaiva tantras such as the BraYā. ${ }^{15}$ Verses $6 \mathrm{~cd}-16$ praise and recommend ritual bathing at a special śivatirtha, in "Śiva's water" or "water embodying Śiva" (śivamaye jale). In the context of the MaSam, it is very probable that what is meant here is bathing in or with, and consuming, urine or other bodily fluids. Mallinson $(2007,221-223$, notes $333-334,336-337)$ has shown convincingly that the practice of bathing with urine was not unknown in Kāpālika and hațhayogic traditions. ${ }^{16}$ On the other hand, in light of the second half of the chapter, it is not inconceivable that semen is what is hinted at here. In either case, the application of this magical fluid involves transgression and thus should be carried out in a secret place (16cd). Verse 18 names the miraculous fluid as amarī, a term echoed in MaSam 27.5 as amarirasa. That chapter, MaSam 27, teaches concoctions of herbs and physical secrations such as fæces, urine, menstrual blood, phlegm (?) and semen (?) (viñ-mūtra-rajo-recaka-sārakāhn) associated with Lokeśa, Keśava, Rudra, İ́a and Sadeśvara, respectively (27.2, see Mallinson [2007, 220 note 328]). In MaSam 27.5a Sadāśiva (i.e. probably Sadeśvara, or rather the substance associated with him, probably semen) is said to be the best among them (sadāśivo varo jñeyas). This may indicate that the meaning of $\operatorname{amari}$ (and sudhā, amrta etc.) is flexible; it may refer not only to urine, but to other bodily fluids as well. Amari should be drunk after reciting the appropriate mantra and should be massaged on one's body $(27.21-26 \mathrm{ab})$, similarly to what is taught in MaSam 40.64-65, where it is clearly semen.

The second part of our chapter, MaSam $40.29 \mathrm{ff}$., commences to further describe kulācāra, and claims that sexual rituals should be performed either with Yoginīs or with Māyā-type women (verse 38). Here follows an edition and translation of verses $29-38$ :

\section{[kulācāranirṇayam $]^{17}$}

ataḥ paraṃ śṛ̣u śive kulācārasya nirṇayam | samprāpya siddhasaṃtānaṃ guruṃ daivaṃ sadā yajet ||40.29||

\footnotetext{
15 E.g. BraYā 3.227, 45.159 and Kubjikāmatatantra 2.107 etc.

16 In a similar fashion, the BraYà (e.g. in 45.427 and 45.456) prescribes the praise of urine to be performed by the sādhaka.

17 This edition of MaSam 40.1-69 is based on four manuscripts: Ja, Jb, Jc, Well (see the bibliography; Jd is not available for chapter 40). The transcription of the text of the MaSam both in the textus acceptus and in reporting variants involves some inevitable falsification, of which the most important are the following: I have not always attempted to report differences in readings between akșaras that are usually interchangable in MSs (b-v,
} 
gurupūjārato yogī parāṃ siddhim avāpnuyāt |

guroḥ khațvāṃ tathā śayyāṃ vastram ābharaṇāni ca ||40.30||

pādukām chattram ajinaṃ pātram anyad athāpi vā |

pādena sprś́ate yas tu śire dhṛtvāṣțakaṃ japet ||40.31\|

gurunindāparaṃ dṛștvā ghātayed athavā śapet |

sthānaṃ vā tat parityajya gacched yady akșamo bhavet ||40.32||

kulapūjāṃ na nindeta yoginaṃ yoginīm api |

unmattāṃ puṣṭitāṃ nārīṃ surākumbhaṃ śivaṃ gurum ||40.33||

nindanād bhraśyate sadyah paratreha ca pārvati |

paśumārgaṃ na seveta paśūcchișțaṃ na kāmayet ||40.34||

yoginīmelanaṃ kāryaṃ na seveta paśustriyam |

nocchișțaṃ paśave dadyāt na nārīṃ nindayet kvacit ||40.35||

ekībhāvaṃ prakurvīta pṛthagbhāvaṃ na kārayet |

vṛthā pānaṃ na kurvīta na vṛthā māṃsabhakṣaṇam ||40.36||

asaṃskṛtaṃ na piben madyaṃ tatpūtaṃ māṃsam āgraset |

na kuryān mantragoṣṭhīṣu śaucam ācamanādikam |

yadi kuryāt pramādena yoginīsāāpa āpatet ||40.37||

bhuñjīyād yat striyam devi śivaśaktyātmabhāvayā |

yoginīṃ sevayen nityaṃ māyāṃ vā pāśavīṃ na ca ||40.38||

Witnesses for MaSam chapter 40: MS Ja: ff. 62r-64r, MS Jb: ff. 126v-13ov, MS Jc: ff. 132r-136r, Ms Well: ff. 8gv-9iv.

29a śive ] J; śide Well ( $p \bar{a} d a$ a is a na-vipulā) 29b nirṇayam ] JaJcWell; nirṇayah Jb 29c siddha $^{\circ}$ ] J; siddhi ${ }^{\circ}$ Well; cf. Kubjikāmata 3.98ab: atraiva siddhasantāne pratyakșo 'ham vyavasthitah 29d gurum ] JaJcWell; guru Jb • yajet ] J; yatet Well 3 3oc khațvām ] J; khadvāṃ Well 31b pātram anyad ] J; pātramadhyam Well 31a na-vipulā $\quad$ 31d tu śire dhṛtvāṣtakam ] conj.; tu śirasi ghṛtvāṣtakam J, u śira ghṛtvāṣtaka Well; cf. Kubjikāmata 3.133cd-134ab [Manthānabhedapracāraratisañgama chapter]: pādukopānahau chattraṃ śayyāpațto 'tha bhājanam | pādena saṃsprśsed yas tu śire dhṛtvāșțakaṃ japet $\| \quad \mathbf{3 2 a}$ ${ }^{\circ}$ nindāo ${ }^{\circ}$ J; ${ }^{\circ}$ nidāa ${ }^{\circ}$ Well (Well's reading would result in two laghu syllables) • dṛsțtāa ] J;

$\mathrm{v}-\mathrm{c}, \mathrm{t}-\mathrm{n}, \mathrm{y}-\mathrm{p})$, but I always report them when both readings are theoretically possible (e.g. candana-vandana, jaya-japa); I have ignored most instances of gemination of consonants in ligature with semivowels (e.g. dharmma); I have treated anusvāras and homorganic nasals as interchangeable; I have altered them, as well as word-final anusvāras and $m$-s, silently as required by standard orthography; instances of confusion between $s ́$ and $s$ are reported only in the non-accepted variants; avagrahas are mostly missing in the Mss and I have always silently supplied them in the textus criticus and in the lemmata, but not when reporting variants; in the apparatus: $\mathrm{em} .=$ emendation; conj. $=$ conjecture; corr. = correction; ${ }^{a c}=$ before correction (ante correctionem); ${ }^{p c}=$ after correction (post correctionem); $\dagger \ldots \dagger$ enclose corrupted text which I have not been able to improve upon; ${ }^{\circ}$ indicates that the word is part of a compound or phrase; $\times$ stands for an illegible akșara; Jab = Mss Ja and Jb; Jall = all available Jodhpur Mss (= Ja, Jb, Jc). 
dṛsțā Well $\quad 3^{2}$ d akșamo ] JaJcWell; amo Jb $\quad$ 33ab nindeta yo $^{\circ}$ ] JWellpc; nindeta yoginimelanam kāryam na seveta paśus trayaṃ nocchișțaṃ pasavo dadyāte Wellac (eyeskip to verse 35) 33b yoginīm ] Jab; yogibhīm JcWell 33c unmattāṃ ] J; unmatāṃ Well • puṣtitāạm ] JaJcWell; puștito Jb • nārīṃ ] Jab; nārī JcWell 33d surākumbham ] Jab; sur×kumbham Jc, surīkumbhaṃ Well 34a nindanād ] JaJcWell; nindanāt Jb • bhraśyate ] JaJcWell; praśyate[?] Jb 34d paratreha ] J; paratredva Well $34 \mathrm{~d}$ paśūcchișțam ] J; paścacchișțaṃ Well $\quad 35$ b $^{\circ}$ striyam ] corr.; ${ }^{\circ}$ striyām J, o strayam Well 35 c paśave ] J; pasavo Well $35 \mathrm{~cd}$ note the absence of sandhi between the two pādas. $\left.\quad \mathbf{3}^{6 \mathbf{6}} \mathrm{ek}^{\circ}{ }^{\circ}\right] \mathrm{J}$; ekvīo Well 37a asaṃskṛtam ] J; aṃskṛtam Well • pāda a is hypermetrical. Cf. Kulapradīpa 3.48: asaṃskṛtam piven madyam balātkāreṇa maithunam | svapriyeṇa hatam māṃsam rauravaṃ narakaṃ vrajet $\quad 37 \mathrm{c}$ kuryān ] Jab; kuryon JcWell •ogoșthīṣu ] Jab; goșthīvu Well 37 f. yoginīsāāpa āpatet ] Jab; yoginī śāyatet Jc ${ }^{p c}$ Well, yogānī śâyatet Jc ${ }^{a c} \quad 38$ a bhuñjīyād ] J; bhujīyād Well • yat ] Jab; ya JcWell $38 \mathbf{b}^{\circ}$ bhāvayā ] conj.; 'ohāvaya JaJc, 'obhāvaye Jb, obhāvayaṃ Well 38c yoginīm ] Jab; yoginī Well • sevayen ] Jab; sevayon Well 38d māyāṃ vā ] Jab; māyāạ cā Jc, māyāṃ ca Well • pāśavīm ] Ja JajbJcWell; pośavīm Ja ${ }^{a c}$ • na ca ] J; na ce Well

\section{[The exposition of Kula Conduct]}

After this, O Śivā, hear the exposition of the Kula Conduct (kulācāra). After he has joined the tradition of the Siddhas, he should worship his guru as divine. (40.29)

The yogin who is engaged in the worship of his guru can obtain the highest Power (siddhi). The guru's bedstead, his bedding, clothes, ornaments, sandals, parasol, antilope-skin, bowl or anything else: if he touches any of these with his feet, he should place them on his head and recite [mantras] eight times. (40.30-31)

If he sees anybody who is abusing the guru, he should beat him or [at least] curse him. Or, if he is unable [to do so], he should leave the place. $(40.32)$

He should not ridicule the worship of the [Yoginī] clans (kulapüjā), or despise yogins or yoginis, women when they are intoxicated, or nourished, ${ }^{18}$ or the wine-pot, or Śiva, or the guru. (40.33)

Contempt [for these] will make him fall immediately here in this world and in the other world, O Pārvatī. He should not follow the path of the paśus [i.e. that of the uninitiated] and he should not long for the leftover of paśus. (40.34)

He should strive for an encounter (melana) with the Yoginīs. He should not have sex (na seveta) with uninitiated women (paśustrī). ${ }^{19} \mathrm{He}$

18 Perhaps: "pregnant." Alternatively, some kind of sexual interpretation is needed here.

19 See 40.38. 
should not give leftovers to the uninitiated ( $p a s i u$ ). He should never abuse women. (40.35)

He should treat [all phenomena] as one, not as separate. ${ }^{20} \mathrm{He}$ should not drink [alcohol] or eat meat idly [with no ritual purpose]. (40.36)

He should not drink wine without first purifying it [with mantras], and he should consume meat after he has purified it with that [wine]. He should not answer the call of nature, should not sip water, etc., while reciting mantras or in an assembly. ${ }^{21}$ If he does so out of folly, the curse of the Yoginīs will fall on him. (40.37)

When (yat) [the yogin] wants to enjoy (bhuñjiy āt) a woman, O Goddess, visualising himself as Śiva [and her as] Śakti, ${ }^{22}$ he should always have sex with a Yoginī or with a Māyā [type of woman], and never with a Pāśavī [i.e. a paśu-natured woman, or more precisely someone who has not been initiated]. (40.38)

Noteworthy among the above are verse 31 , which is more or less parallel with Kubjikämatatantra 3.133cd-134ab, reconfirming that the cult of the MaSam draws heavily on the Paścimāmnāya; ${ }^{23}$ verse 33 , which warns against the abuse of women; and verse 35, which seems to mention only Yoginīs (recommended for sexual encounters) and uninitiated women (not recommended), and seems to be silent on any other category, in contrast to verse 38 , in which the third type, Māyā, first appears.

The subsequent verses, 40 and 41, define a Yoginī: she follows the Kula path, is initiated, uses alcohol in her rituals, and generally gives the impression of being a human female practitioner. Rather awkwardly, the text does not give any other detail, but goes on defining her antithesis, the Pāśavì: an uninitiated woman, who is hostile to Śaivism and who should be avoided (41cd-42).

A sexual ritual with the third type, Māyā, is what the rest of the text focuses on. It is here that major ambiguities come into the picture. The key aspects mentioned in the description of the Māyā-type woman are: she has all the

20 I suspect that here the principles of non-hesitation (nirvikalpa) and freedom from conventional practices (nirācāra) are being reaffirmed: the practitioner should not distinguish between right and wrong, pure and impure etc. See 40.1-28.

21 The interpretation of mantragoșthiș̣u is highly tentative.

22 The compound śivaśaktyātmabhāvayā (conj;; ’bhāvaya JaJc, ’bhāvaye Jb, bhāvayaṃ Well) is rather unusual, and my conjecture is insecure. Perhaps ${ }^{\circ} b h \bar{a} v a y \bar{a}$ stands for bhāvanaya metri causa. The intended meaning seems to be clear, though. 
auspicious characteristics required (sarvalakșaṇasampannā), has neither rūpa nor kula (kularüpavivarjitā $),{ }^{24}$ and is to be approached by bhāva (bhāvagamyā, $40.43) .{ }^{25}$ All of these terms remain rather ambiguous without the help of clarification based upon other passages. Here follows the text and translation of this section:

\title{
[yoginī māyā pāśavī ca]
}

\author{
devy uvāca | \\ kā nārī yoginī deva kā māyā kā ca pāśavī| \\ etāsāṃ saṃgame doṣaṃ guṇaṃ ca vada bhairava ||40.39\|
}

\section{[yoginī]}

\author{
bhairava uvāca | \\ kulamārgagatā nārī paśumārgavivarjitā| \\ mādhvīmadasamādhmātā paśupāśavivarjitā |40.40|| \\ madirānandacetaskā yoginī śivaśāsane |
}

\section{[pāśavī]}

\author{
vikalpakuṭilā pāpā kulācāraparānmukhī ||40.41\| \\ śivanindāparā devi tatsaparyāvirodhinī | \\ pāśavī sā mayākhyātā māyākhyāṃ śṛ̣u suvrate ||40.42\|
}

24 That kula and rūpa are to be understood as a dvandva compound is confirmed in 40.44ab: yā māyà rūparahitā kulahīnà maheśvara.

25 Elsewhere I have argued (Kiss 2009, 57-6o) that while bhāva in the MaSam is mostly to be interpreted as "visualisation," which is a rather common meaning for this word, an additional specification may be required: bhāva refers to a particularly emotive process of creating mental images. I suspect that bhāva is preferred in the MaSam to dhyāna (although dhyāna, dhyāyet etc. also abound) for its extremely wide range of meanings. One of the basic meanings of bhāva is "being, becoming." Another is "emotion, sentiment" or even "passion, love." I think that all these rather different senses of the word are condensed in the yogic key term of bhāva in the MaSam. It is a creation of something in the mind by the yogin, towards which he should also create a feeling, an empathic attitude, perhaps passionate devotion, which will result in the ultimate condition, the desired state of mind: the union with the object, with the deity, with Śiva, or in our case, with a visualised goddess. 


\section{[māyā]}

sarvalakṣaṇasampannā kularūpavivarjitā |

bhāvagamyā maheśāni yā sā māyā nigadyate ||40.43\|

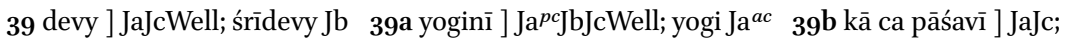
kāśavī Jb, kā ca pāśavīḥ Well 39d bhairava ] J; bhairavah Well 4oa nārī ] JbJcWell; ttārī Ja $\quad 40{ }^{\circ}{ }^{\circ}$ vivarjitā ] J; ${ }^{\circ}$ vivarjitāḥ Well 4ocd mādhvīmadasamādhmātā paśupāśavivarjitā ] em.; mādhvīmadasamādhyātā paśupāśavivarjitā Jab, JcWell omit this line $\quad 4 \mathbf{1 b}{ }^{\circ}$ śāsane ] JaJcWell; `śāsanāt Jb $\quad 4 \mathbf{4 c}{ }^{\circ}$ kuṭilā ] J; ${ }^{\circ}$ kuṭikā Well $\quad$ 41d ${ }^{\circ}$ parānmukhī ] Ja ${ }^{p c J b J c W e l l ; ~}$ ${ }^{\circ}$ pa $\times$ ṅmukhī Ja ${ }^{a c} \quad \mathbf{4 2 a}^{\circ}$ parā ] J; ${ }^{\circ}$ paro Well • devi ] JaJcWell; devī Jb $\quad \mathbf{4 2 b}^{\circ}$ virodhinī ] corr.; ${ }^{\circ}$ virodhitī J, ${ }^{\circ}$ virodhinīm Well $\quad$ 42c pāśavī ] J; pāśavīḥ Well • sā ] J; sa Well $\quad$ 42d ॰ākhyāḥ ] corr.; ${ }^{\circ a ̄ k h y a h ~ J W e l l ~} 4 \mathbf{4 3}^{\circ}{ }^{\circ}$ vivarjitā ] J; ${ }^{\circ}$ vivarjitāḥ Well

\section{[Yoginī, Māyā and Pāśavī]}

Devī spoke:

O God, what kind of a woman is a Yoginī? Who is Māyā and who is Pāśavī? Tell me, O Bhairava, the pros and cons of having sex with them. (40.39)

Bhairava spoke:

A woman who is on the Kula Path [of the Yoginī clans] (kulamärga), who avoids the path of bound souls (paśumārga) [i.e. the path of the uninitiated], who is elevated by intoxication induced by liquor, and is free of the bonds that fetter the soul (paśupāśa), and whose mind is filled with the bliss of wine (madirā), is [called] a Yoginī in Śiva's teaching. (40.40-41ab)

[Pāśavī:] her mental attitude is dishonest, she is wicked, hostile to Kaula Practice (kulācāra). She tends to abuse Śiva, O Goddess, and to obstruct his worship. This [type], the Pāśavī, has been [now] taught by me. O Suvratā, hear the one that is called Māyā. (40.41cd42)

A woman who possesses all favourable characteristics (lakșana) [but] has neither a [Yoginī] Clan/noble family (kula) nor a [human/material] form/beauty (rüpa), and who is to be approached by empathic imagination (bhāva), O Maheśānī, is called Māyā. (40.43)

The term rüpa in 43b may refer to "material form" and a lack of rūpa would then indicate that Māyā, the preferred sexual partner, is solely imaginary. In this case sarvalakșanasampannā indicates that she is to be visualised as a divine being with great beauty. But how to interpret "devoid of kula" then? The term kula is 
often used in the sense of "a clan of Yoginīs." ${ }^{26}$ Is she then not a member of any Yoginī clan? Does she transcend the clans of Yoginīs, being the supreme Goddess?27 This interpretation is supported and at the same time refuted by MaSam 22.24 (which in fact is a citation of Nityāṣodaśikārnava, alias Vāmakeśvarīmata, 4.14):

\section{kulayoșit kulaṃ tyaktvā paraṃ puruṣam eti sā | nirlakșyạ̣ ${ }^{28}$ nirgunam caiva kularūpavivarjitam $\| 22.24||^{29}$}

That noble lady abandons her family (kula) and goes to the highest man, who is invisible, who lacks qualities, and is devoid of kula and form.

Here, in the MaSam as well as the Nityāsodaśikärnava, the supreme soul (param purușam) is described as having neither kula nor rüpa: as being immaterial and formless. ${ }^{30}$ But the word kula is used in a double sense in the case of the female subject of the sentence (kundalini in fact): she leaves her/the body to unite with the Supreme Soul as a noble lady (kulayoșit) leaves her family (kulam tyaktvā) to unite with her husband. This does not make it easier to interpret MaSam 40.43b (kularüpavivarjitā): the sexual partner might be a woman who was not born in an eminent family, i.e. is of low birth (kulavivarjitā), and who lacks beauty (rūpavivarjitā), "beauty" being a natural way

26 See e.g. Sanderson (1988, 671-672): "All Yoginīs belong to the family (kula) or lineage (gotra) of one or other of a number of 'higher' maternal powers, and in any instance this parentage is ascribed on the evidence of certain physical and behavioural characteristics. An adept in the cult of Yoginis can identify members of as many as sixty-three of these occult sisterhoods, but is most vitally concerned with the eight major families of the Mothers (mātṛ) Brāhmī, Māheśvarī, Kaumārī, Vaiṣnavīi, Indrāṇī, Vārāhī, Cāmuṇ̣ā and Mahālakșmī." See also Hatley (2007, 13-23, 33, 392, etc.).

27 Cf. Tāntrikābhidhānakośa, vol. I, sv. akula: "Dans les traditions (āmnāya*) du Kula, c' est la Réalité lumineuse suprême, l'absolu inconditionné: anuttaraṃ param dhāma tad evākulam ucyate (Tanträloka 3.143ab)," etc.

28 em.; nirlajjạ̣ Cod.

29 Cf. Nityāṣoḍaśikārṇava 4.14: kulayoṣit kulaṃ tyaktvā param puruṣam eti sā | nirlakṣaṇam nirgunam ca kularūpavivarjitam $\|$.

3o Cf. Jayaratha ad Nityāṣoḍaśikārṇava 4.14: tadā kulam śarīram apahāya akulapadāvasthitạ̣ param pūrnam [...] kulena śarīreña taddharmeṇa rūpeṇa ca vivarjitam nirāvarañasvabhāvam, ata eva nirguṇam purușam, param pramātāram, eti tadaikātmyam āsādayatīty arthah ("Then leaving behind the kula, i.e. the body, she goes to the one who is in the realm of akula, the supreme, i.e. full [...] Person, the highest authority, who is without a body and without bodily form, with his innate nature manifest and therefore lacking qualities, i.e. she reaches oneness with Him. This is the meaning [of this verse].") 
of translating rüpa. In this case, sarvalakșanasampannā (40.43a) refers to the form she assumes during the yogin's visualisation, and bhāvagamya (40.43) may suggest that a sexual ritual with her requires this visualisation. Alternatively, the ideal sexual partner might be one who is immaterial and formless (kularūpavivarjitā ): a visualised goddess, or, as a matter of fact, kundalinī. As we have seen, in the context of the yogin's sexual rituals, first two, then three types of partners are enumerated: one, who is hostile to Saivism, is to be avoided; initiated human Yoginīs are ideal, but are not dwelt upon in the text, perhaps because they were less and less available at the time of the composition of the MaSam; and as a third alternative, the text either suggests pure visualisation or an uninitiated woman of low birth, without any particular charm, as the locus of visualisation of the Goddess.

The text goes on to give instructions on visualisation needed for the sexual ritual. The yogin should visualise himself as Śiva in the form of Kāmeśvara, and his partner as a goddess:

\section{[māyayā saṃgaḥ]}

devy uvāca |

yā māyā rūparahitā kulahīnā maheśvara |

yoginaḥ samgamas tasyāḥ kathaṃ bhavati tad vada \|40.44\|

bhairava uvāca |

śṛ̣u devi pravakṣyāmi māyayā saṃgam adbhutam |

yad amoghaṃ maheśāni durvijñeyam utāparaị̣ ||40.45\|

yogasiddhivihīnaiś ca yogibhị̣ suranāyaki |

44 uvāca ] JaJc; u- Jb, uvā- Well 44a yā ] J; omitted in Well (pāda a is a na-vipulā) $\mathbf{4 4 b}$ maheśvara ] Well; maheśvarah J 44c yoginah ] JaJc; yogina Jb, omitted in Well 44d kathah ] conj;; vāthah J, cāthah Well • vada ] Jab; vadah JcWell 45 uvāca ] JaJcWell; u- Jb 46a `vihīnaiś ] JaJc; vihītaiś Jb, vihīnaihś Well 46b yogibhih ] J; yogibhīh Well • suranāyaki ] JaJcWell; suranāyakih Jb

\section{[Sexual ritual with Māyā]}

The Goddess spoke:

Tell me, O Maheśvara, how should the yogin sexually approach the one who is called Māyā, who has neither form/beauty (rūpa) nor a clan/noble family/body (kula)? (40.44)

Bhairava spoke:

Listen to me, O Goddess, I shall teach you the extraordinary intercourse (saṃga) with Māyā. It is fruitful, O Maheśānī, and difficult to learn 
by others and yogins without yogic Powers (siddhi), O Suranāyakī. $\left(40.45^{-46 a b)}\right.$

\section{[parameśvaradhyānam]}

sugupte mandire mantrī mṛdvāsanaparigrahah ||40.46||

bhāvayec ca svam ātmānaṃ parameśvaravigraham | kāmeśvaram ivādyantam sūryāyutasamaprabham ||40.47|| cārumañjīrakeyūrakuṇḍalāngadabhūṣitam | mudrikāchannahīrādikirīṭamukuṭojjvalam ||40.48|| prasannavadanaṃ kāntạ̣ tāmbūlāpūritādharam | madirānandacetaskaṃ paramānandavigraham ||40.49\| navayauvanasampannaṃ sarvalakṣaṇabhūṣitam | svavāmabhāgavinyastamahājagavakārmukam ||40.50|| dakṣabhāgojjvalatpañcaśaram indīvaradyutim | nīlotpalalasanmālābhūṣitoraskam īśvaram ||40.51|| madena kṣubdhahṛdayam īṣāsmitamukhāmbujam | evaṃ dhyāyec ciraṃ yogī svaśarīraṃ śivātmakam ||40.52|| candanāgarukarpūrakurañgajayakuñkumaị̣ | adhivāsitasarvāñgạ̣ cāruvaktravirājitam ||40.53\| ratnadvīpāyutayutaṃ gehe sattalpamadhyagam |

46c sugupte mandire ] J; sugupto māḥdere Well 46d mṛdvāsana ${ }^{\circ}$ ] J; mṛddhāsana ${ }^{\circ}$ Well $^{2}$

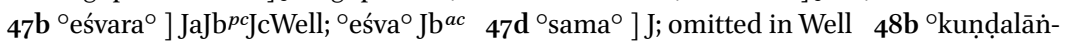
gadabhūṣaṇam ] Jab; ${ }^{\circ}$ kuṇualāngadabhūṣitam Jc, 'kumbhalāngadabhūṣitam Well 48d oojjvalam ] Jc; ${ }^{\circ}$ ojvalam JabWell 49a prasannavadanah ] JaJc; prasahnah vadanah Jb, prasannavadanāḥ Well $\quad 49$ bāmbūlāpūritādharam ] JabWell; tāxbūlāpūridharam Jc ${ }^{a c}$, tāxbūlāpūritādharam Jc ${ }^{p c} 5^{\text {od }}{ }^{\circ}$ mahājagava ${ }^{\circ}$ ] conj.; ${ }^{\circ}$ mahadaikșava , $^{\circ}$ mahavaivakșa ${ }^{\circ}$ Well 51a dakșa $\left.{ }^{\circ}\right] \mathrm{J}$; rakșa ${ }^{\circ}$ Well • ${ }^{\circ}$ ojjvalat $^{\circ}$ ] corr.; ${ }^{\circ}$ ojvalat $^{\circ}$ JWell $_{51 \mathbf{1 c} \text { nīlotpala }}^{\circ}$ ]

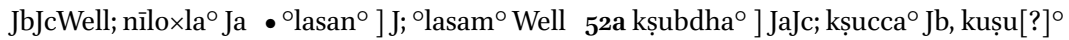
Well $\quad 5^{2}$ b īṣāsmita ${ }^{\circ}$ ] J; îsmita ${ }^{\circ}$ Well • mukhāmbujam ] JaJcWell; mukhāḥ Jb $\quad \mathbf{5}^{\mathbf{2 a}}$ navipulā $\quad 52 c$ cirah ] J; cīrah Well $5 \mathbf{5 3}^{\circ}$ āgaru $^{\circ}$ ] J; ${ }^{\circ}$ ăgara $^{\circ}$ Well $\bullet{ }^{\circ}$ karpūra $\left.{ }^{\circ}\right]$ JaJcWell; ${ }^{\circ}$ karpūraḥ Jb $53^{\mathrm{d}}$ cāru $\left.{ }^{\circ}\right] \mathrm{J}$; cāruh Well • ${ }^{\circ}$ virājitam ] J; ${ }^{\circ}$ virājitaḥh Well $\quad$ 54a na-vipulā $\left.\mathbf{5 4} \mathbf{b}_{\text {gehe sattalpa }}{ }^{\circ}\right] \mathrm{Ja}$; gehe satralpa ${ }^{\circ} \mathrm{JbJcWell}$

\section{[Visualisation of Parameśvara]}

In a hidden sanctuary, the mantra master should sit on a soft cushion ${ }^{31}$ and should visualise himself as having the body of Parameśvara, as if

31 The element oparigrahah in the compund mrdvāsanaparigrahah is suspicious. A word meaning "seated" would fit the context better. 
[he were transformed into] Kāmeśvara, ${ }^{32}$ having no beginning and no end, shining like millions of suns. (40.46cd-47)

$\mathrm{He}$ is adorned with nice anklets, armlets, rings and bracelets, and he shines with small toe rings (mudrikā), ${ }^{33}$ channahiras, ${ }^{34}$ etc., and diadems and a crown. (40.48)

His face is gracious, beautiful, his lips are smeared with betel leaves. His mind is filled with the joy of wine,$^{35}$ and his body is supreme bliss [itself]. (40.49)

He is in the prime of his youth and has all the auspicious characteristics. He has the great Ajagava ${ }^{36}$ bow placed on his left side. (40.50)

On his right, he has five glowing arrows. He is shining like a blue lotus. On his chest there is a glittering garland of blue lotuses. He is the Lord. (40.51)

His heart is agitated with sexual desire. His lotus face displays a faint smile. ${ }^{37}$ This is how the yogin should visualise his body for a long time, as transformed into Śiva. (40.52)

All his limbs are perfumed with sandal, aloe, camphor, musk ${ }^{38}$ and saffron. He has a beautiful face. (40.53)

He is surrounded by millions of gem islands, in a chamber on a fine bed. ${ }^{39}(40.54 \mathrm{ab})$

32 Note that Kāmeśvara features as Śiva or the central deity in the pre-Śrīvidyā Dakṣināamnāya tradition, with which the MaSam is clearly affiliated. See Sanderson $(1988,688)$, and Kiss (2009, 18 and 42-43).

33 This is somewhat tentative. See mudrikā as an ornament in Brahmayāmala 21.63cd: mudrikām añguliś caiva pādau laktakarañjitau (Kiss 2015, 219).

34 A channahīra, or rather a channavira, is made up of two sacred threads (yajñopavita) worn over the two shoulders and across the chest. Bunce (1997) provides two definitions: "Channavira-(Ind.: channa-vīra) A Hindu iconographic object for bodily adornment. The term channavira refers to a chain worn by both male and female deities. It is made up of two chains crossed over the chest, a disc covers the front crossing" (Bunce 1997, 58). "The term chhannavira refers to two sacred cords similar to yajñopavita. One is placed over each shoulder, crossing on the chest and back and looping as low as the hips" (Bunce 1997, 63). See also Rao 1914, vol. 1.2, xxxi (Addenda), where it is defined as a double yajñopavita. See channavīra mentioned in e.g. Rauravāgama, Kriyāpāda 10.52d.

35 Note that here intoxication is something only to be visualised.

36 Note that mahäjagava is a rather insecure conjecture for mahadaikșava and mahavai$v a k s ̦ a$. Other variants of the name of Śiva's bow are ajakava and ajikava.

37 Note the slightly odd form $\overline{\iota s} \bar{a} s m i t a^{\circ}$ metri causa for the standard issadasmita ${ }^{\circ}$.

38 I take kurangajaya in the sense of "musk," although I have not found any evidence for this compound being used instead of the well-known kurariganäbhi. I am grateful to Harunaga Isaacson for his assistance with this passage. 


\section{[śaktidhyānam]}

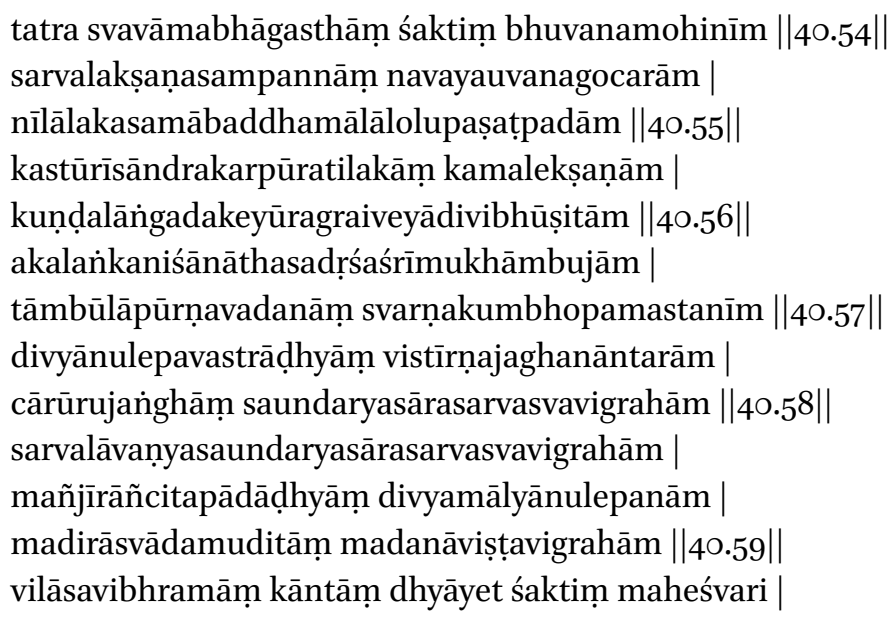

$\left.54 \mathrm{c} \mathrm{sva}{ }^{\circ}\right]$ JaJcWell; omitted in Jb $55^{\circ}{ }^{\circ}$ gocarām ] J; ${ }^{\circ}$ gaucarām Well $55^{c}$ nīlāo $]$ conj;; līlāo

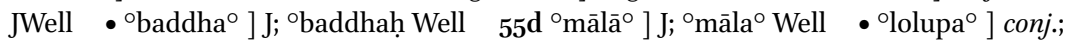

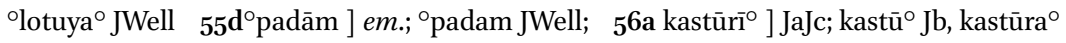
Well $56 \mathbf{b}^{\circ}$ tilakāh ] J; ${ }^{\circ}$ tilaḥkāh Well $\bullet{ }^{\circ}$ ekșaṇām ] Jab; ${ }^{\circ}$ ekșaṇam JcWell $56 \mathbf{c}^{\circ}{ }^{\circ}$ keyūra ${ }^{\circ}$ ]

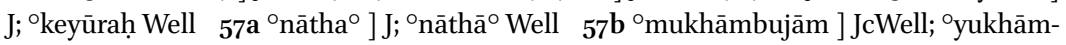
bujāh Ja, ${ }^{\circ}$ yukhāmbujah Jb ${ }_{57} \mathbf{d}^{\circ}$ opamastanīm ] Ja; ${ }^{\circ}$ opastanīm Jb, ${ }^{\circ}$ opamastakīm JcWell

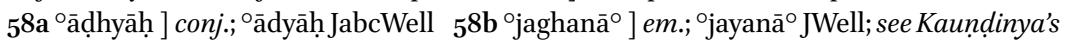
commentary on Pāśupatasūtra 1.9: adhomukhenādaṃșțeṇa jaghanāntaracārināā $\quad 58 b$ ${ }^{\circ}$ ntarām ] JaJcWell; ${ }^{\circ}$ ntaram Jb $\quad 58 \mathrm{c}$ saundarya $\left.{ }^{\circ}\right] \mathrm{J}$; soṃdaryam ${ }^{\circ}$ Well $\quad \mathbf{5}^{\mathbf{8 d}}{ }^{\circ}$ vigrahām ] Jab; ${ }^{\circ}$ vigraham JcWell $\quad 58 \mathrm{c}$ ma-vipula $\quad$ 59a ${ }^{\circ}$ pādāḍhyāṃ ] Ja; ${ }^{\circ}$ pādādyāṃ JbJc ${ }^{p c}$, ${ }^{\circ}$ pādyādām Jc ${ }^{a c}$, ${ }^{\circ}$ ādāyāṃ Well $59^{\circ}{ }^{\circ}$ mālyānulepanām ] Ja ${ }^{p c} \mathrm{Jb}{ }^{\circ}{ }^{\circ}$ mālyānulepanam Ja ${ }^{a c}$, ${ }^{\circ}$ mālānulepanām JcWell $59 \mathrm{~d}$ madanāviștạ ${ }^{\circ}$ ] Jab; madanāo JcWell 59a na-vipulā 6ob dhyāyet ] Ja ${ }^{p c}$ Jc; dhyā Ja ${ }^{a c}$, dhyāye Jb, madhyāt Well • śaktiṃ ] J; sakti Well

\section{[Visualisation of Śakti]}

On his left side, [he should visualise] Śakti, who infatuates the world. (40.54cd)

She has all the auspicious characteristics. She is in the prime of her youth. She has bees longing for the garland tied in her black locks. (40.55)

The tilaka-mark on her forehead is made with musk thickened with camphor. She has lotus-eyes. She is adorned with rings, armlets, anklets, necklaces etc. (40.56)

Her beautiful lotus face resembles the spotless moon. Her mouth is filled with betel. Her breasts are like golden jars. (40.57) 
She is anointed with divine ointments and she is dressed in divine clothes, with her loins exposed. ${ }^{40}$ Her thighs and shanks are beautiful. Her body is the ultimate essence of gracefulness. (40.58)

Her feet are embellished ${ }^{41}$ with anklets. She wears divine garlands and [has been anointed] with divine ointments. She is delighted by the wine she is enjoying. Her body is filled with passion. She is restless with wantonness. [This is how the yogin] should visualise his lover (kāntā) as Śakti, O Maheśvarī. (40.59-6oab)

The appearance of Kāmeśvara and the mention of a gem-island (ratnadvīpa) in the above verses suggest an affiliation with the Śrividyā tradition and with love magic, perhaps with that of the pre-Śrīvidyā Dakșināmnāya tradition. ${ }^{42}$ Verse 46cd ("in a hidden sanctuary") may also be revealing: if the whole ritual were purely imaginary, it would be less important to perform it in a secret place.

Going further in our text, MaSam 40.6ocd-68 may also suggest that a real sexual encounter is being described by using words such as âslisya ("embracing"), samācaret ("he should perform"), bahih ("outwardly"), kșipet ("place [his hand]"), vimuñcati ("ejaculates"), by giving instructions in 40.61 to stimulate the partner, and also by avoiding words that would refer to visualisation, except dhyanne, probably hinting at the fact that the whole process is accompanied by a projection of the image of the Goddess onto the female partner. On the other hand, the formulation of verse 40.65 may cast some doubt upon the real-life presence of the female partner: the yogin should rub his semen on his body, and there is no mention of the female partner's sexual fluids or her receiving or consuming any of the magical mixture, a common practice in Śaiva sexual rituals. ${ }^{43}$ Here follows the end of the chapter, describing the sexual ritual:

40 Ex em. Compare Kauṇdinya's commentary ad Pāśupatasūtra 1.9 (p. 14): adhomukhenādaṃștreṇa jaghanāntaracārịnā | sarvaśāstrācikitsyena jagad daștam bhagāhinā $\|$, which is translated by Hara $(1966,196)$ as "The world is bitten by a snake whose mouth is below, toothless, who has crawled between the loins and whose poison can be cured by no science. Its name is the vulva." The passage can also interpreted as "The world is bitten by the snake of the vagina whose toothless mouth points downward, and who moves in the genital area, and for which there is no antidote."

41 I have translated añcita as "embellished," suspecting that the word may need some emendation (ankita/rañjita?).

42 See Sanderson 1988, 688-689 and 2009, $47 \mathrm{ff}$.

43 See e.g. BraYā 45.201-202ab (Kiss 2015, 142, 258): upaviśyāpayet tatra cumbanādyāvagūhanam | krtvā kṣobham samārabhya pavitram grhya sādhakah || prāśayitvā tu tau hrșțau yāgadravyāni prokșayet |. "The Sādhaka should make [her] sit down there. He should start kissing and embracing her and stimulating her. He should collect the purifying [substance, i.e. the sexual fluids]. Overjoyed, they should consume [the fluids] ..." 


\section{[samgah]}

āśliṣya cumbanādīni yogī samyak samācaret ||40.6o || dhyāne bahị̣ susaṃsnigdhaṃ tayā saṃgam samācaret | gajahastaṃ kṣipet tasyāḥ śrīmanmadanamandire ||40.61\| mantram enaṃ smared yogī madạ̣ yāvad vimuñcati | bhautikavyoma †lā aiṃ̣̣i † kevalārṇas tu bhautike ||40.62 || aparo vahni vāmākși bindu yukto maheśvari | CALEPadạ̣ CALApadam CITREpadam anantaram ||40.63\| RETOpadaṃ MUÑCApadayugaṃ pūrvabījā vilomagāḥ | evaṃ krameṇa yo yogī māyāsaṃgaṃ samācaret ||40.64|| tadvīryam svarṇakarpūrakuñkumādiviloḍitam | svadehaṃ mardayet kāntiś candravat samprajāyate \|40.65\| samūlāṃ brahmamaṇụūkīṃ chāyāśuṣkāṃ prasādhayet | mṛdvīkārasasaṃmiśrāṃ śarkarāghṛtamelitām ||4o.66|| trimāsaṃ bhakșayet kālatrayam akṣapramāṇakam | annapānaṃ payaḥ pītvā nāsya śukraḥ kṣayaṃ vrajet ||40.67|| śatavarșasahasrāntaṃ yadi saṃgaṃ samācaret | nāsya prakṣīyate satyaṃ navatvāptyai tanoh priye ||40.68|| rasāyanam idaṃ guhyam anyeșāṃ na prakāśayet | etad rahasyaṃ vyākhyātaṃ durlabhaṃ siddhasaṃtatau | gurukārunyasaṃlakșyaṃ kiṃ bhūyah śrotum icchasi ||40.69|| || iti śrīmatsyendrasaṃhitāyāṃ catvāriṃśaḥ pațalạ̣ ||

6oc cumbanā̄o ] J; cumbunā $\bar{a}^{\circ}$ Well $\quad$ 6od samyak ] JaJc; samyā[?]k Jb, samyas Well samācaret ] Ja ${ }^{p c J b W e l l ; ~ s a m a ̄ c a r e ~ J a ~}{ }^{a c} \quad 61$ dhyāne ] Jab; dhyāye JcWell • bahị̣ ] corr.;

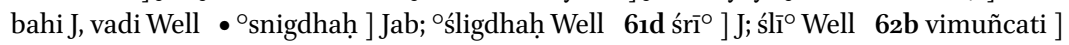
JaJcWell; vimuhtica Jb (metathesis) 62d kevalārṇas ] J; kaivalārṇas Well • tu bhautike ] J; tv abhautike Well 62 marginalia in f. 64 r of Ja (top $)$ : HRAIM TVAIM RĪM CATE VATA CITTE RETO MUÑCA 2 RỊ̇ KLAIṂ HRAIṂ. 63a vahni ${ }^{\circ}$ ] Well; vahvi ${ }^{\circ} \mathrm{J}$ 63. $\mathbf{b}$ bindu $^{\circ}$ ] J; bindud ${ }^{\circ}$ Well • maheśvari ] J; maheśvarī Well 63 cale $^{\circ}$ ] J; cile ${ }^{\circ}$ Well • cala ${ }^{\circ}$ J; calāo Well $64 a$ muñcapada ${ }^{\circ}$ ] corr.; muñcapadam J, mucapadam Well 64 a hypermetrical $64 b^{\circ}$ yugam

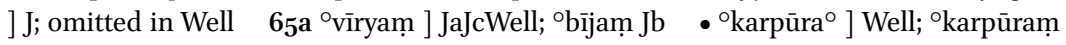
J 66b chāyāo ${ }^{\circ}$ J JaJcWell; chāyāṃ ${ }^{\circ} \mathrm{Jb} \quad \bullet{ }^{\circ}$ śușkāṃ ] J; ${ }^{\circ}$ śu×āṃ Well $\quad 65$ c mardayet ] J; marddhayet Well $\quad 66 \mathbf{c}^{\circ}$ miśrāṃ ] J; ${ }^{\circ}$ miśrom Well $\quad$ 66d ${ }^{\circ}$ melitām ] JaJcWell; ${ }^{\circ}$ melikām Jb 67a trimāsam ] J; trimāse Well • kāla ${ }^{\circ}$ ] JaJcWell; kāo Jb $\quad 67 \mathrm{~d}^{\circ}$ pramāṇakam ] Jab; opramāṇakraṃh Well $\quad 67 \mathrm{c}{ }^{\circ}$ pānam $] \mathrm{J}$; ${ }^{\circ}$ pātam Well $\quad 68 \mathrm{~b}$ saṃgam ] corr.; saṃga JWell 68c nāsya ] Ja; nākșasya Well • satyam ] JbWell; xyam Ja 68d navatvāptyai ] JaJcWell; navātvāstha Jb 69a guhyam ] J; guhyammm Well 69d 'labham ] J; ’lebham Well 69e 'kāruṇya ${ }^{\circ}$ ] JabWell; ${ }^{\circ}$ āruṇyaṃ Jc $\quad 69$ f. bhūyah ] J; bhūya Well • śrotum ] JaJcWell; śrītum Jb Colophon: catvārimśah ] J; catvāriṃśat Well 


\section{[The intercourse]}

The yogin should embrace and kiss her, etc., properly. (40.6ocd) [Then] he should have sex with her outwardly, very gently, while [performing] visualisation. He should apply the "elephant trunk" [method] ${ }^{44}$ on her divine love temple [i.e. her genitalia]. (40.61)

The yogin should recall this mantra when he ejaculates: Bhautika $[\mathrm{AI}]$, Vyoman $[\mathrm{H}],[\ldots]$, TU verbatim and Bhautika [AI; i.e. HRAIM TVAIM $]^{45}(40.62)$

Moreover: Vahni [R] and Vāmākṣi [Ī] with a Bindu [Ṃ; i.e. RĪṂ], O Maheśvarī, the words CALE and CALA and immediately CITRE [CITTE?], (40.63)

the word RETO, MUÑCA twice, ${ }^{46}$ and the previous seed-mantras backwards [RỊ̣̄ TVAIṂ HRAIṂ]. The yogin who has had sex with Māyā should rub his semen mixed with gold, camphor and saffron on his own body: [his] beauty will become moon-like. (40.64-65)

He should dry brahmamand $\bar{u} k \bar{l}^{47}$ together with its roots in the shade. He should mix it with grape-juice, candied sugar and ghee. (40.66) He should have it three times [a day] for three months in portions measuring a dice as food and drink and he should drink milk. His semen will not deteriorate in millions of years if he practises sex [with Māyā]. His [semen] will never ever wane. It is for the rejuvenation of the body, O Priyā. (40.67-68)

This is the secret of alchemy. He should not reveal it to others. This secret of the Siddha tradition, which is difficult to obtain, has now been taught. It is to be revealed through the compassion of the guru. What else do you wish to hear? (40.69)

Here ends the fortieth chapter of the Matsyendrasamnhitā.

\footnotetext{
44 See p. 443 below.

45 If the decoding of this mantra in the marginalia in f. 64r of MS Ja (top, HRAIM TVAIM RĪM CATE VATA CITTE RETO MUÑCA 2 RĪṂ KLAIṂ HRAIṂ) is more or less correct, the puzzling syllables $l \bar{a}$ aim dị must stand for R. Note the slight differences between the code in the text and the mantra given in the marginalia. The reconstruction of the mantra is somewhat tentative.

46 See Kaulāvalīnirnaya 5.51: AMU KỊ̣̄ DRĀVAYA SVĀHĀ vinyaset sādhakottamaḥ| vāmāyā̄[?] CAPALACITTE RETO MUÑCAdvayam pațhet.

47 Clerodendrum Siphonantus?
} 
Rubbing one's own semen on one's body (verse 65) is an old custom, and was probably not considered a transgressive practice at all. Brhadāranyakaupanișad 6.4.4-5 describe a practice to be followed in case one discharges semen:

bahu vā idaṃ suptasya vā jāgrato vā retah skandati || 6.4.4 || tad abhimṛśed anu vā mantrayeta-yan me 'dya retạ̣ pṛthivīm askāntsīd yad oṣadhīr apy asarad yad apah | idam ahạ̣ tad reta ādade | punar mām aitu indriyam punas tejah punar bhagah | punar agnir dhiṣnyā yathāsthānaṃ kalpantām | ity anāmikāngușțhābhyām ādāyāntareṇa stanau vā bhruvau vā nimrjyyāt ||6.4.5||

In Hume's translation (1921, 168-169):

"[If] even this much semen is spilled, whether of one asleep or of one awake, [5] then he should touch it, or [without touching] repeat:'What semen has of mine to earth been spilt now,

Whate'er to herb has flowed, whate'er to water-

Again to me let vigour come!

Again, my strength; again, my glow!

Again the altars and the fire

Be found in their accustomed place!'

Having spoken thus, he should take it with ring-finger and thumb and rub it on between his breasts or his eye-brows." 48

As can be seen from this passage, semen was probably never considered so impure as to forbid its magical application on the body, and this practice was recommended to regain strength-exactly as in MaSam 40.68 (navatvāptyai tanoh). The question is inevitable: is the somewhat similar practice in MaSam 40.65 recommended for a similar situation, namely for ejaculation in a state of mind comparable to sleep, i.e. visualisation? Does this similarity between the two instructions suggest the absence of the female partner in the MaSam?

To return to 40.61cd, where stimulation of the partner is probably hinted at: this gives the instruction to "cast an 'elephant trunk' on the partner's divine love temple" (gajahastam kșipet tasyāh śrimanmadanamandire). This again is ambiguous. Gajahasta could be a mudrā to be shown during the ritual, ${ }^{49}$

48 I find Olivelle's translation $(1996,88)$ slightly less accurate at this point, although the differences are minor.

49 See e.g. Kaulāvalīnirnaya 17.133-135ab: eșā tu paramā mudrā sarvasañkṣobhaṇī matā | 
but could as well be the technique mentioned in Jaśodhara's commentary ad Kāmasūtra 7.2.2:

ratasyopakrame sambādhasya kareṇopamardanaṃ tasyā rasaprāptikāle ca ratayojanam iti rāgapratyānayanam |

Commentary: ratasyeti | samprayogasya upakrama iti | ayam ārambhe, yady api mando rāgo rate pravartayati stabdhalingatvāt, tathāpi prathamatah sambādhasya bhagasya kareṇopamardanam gajahastena kṣobhaṇam kāryam ...

[When you are] about to practise sex, [first you should] rub her genitalia with your hand, and when there is dampness, the sexual act can be commenced. This is the restoration of passion.

Commentary: "about to practice sex": at the beginning of the sexual act. This is at the start [of the sexual act]. Even if the passion is weak with regards to sex because the penis is inert, first "her genitalia," i.e. her vulva, should be rubbed with his hand, should be stimulated with the "elephant trunk" [method] ...

The possible hint in MaSaṃ 40.61cd at a Kāmaśāstric technique again suggests that we are dealing with the description of a sexual ritual involving a human female partner. Or should this also be only visualised?

\section{$3 \quad$ Why All These Ambiguities?}

I think it is safe to say that the teaching of MaSam 40 is ambiguous to an extent that makes it rather difficult to decide on one or another exclusive interpretation. The question to answer is rather: why is it so ambiguous? Is it deliberately so? Is it so due to bad writing, to sloppy composition? Are essential details left out because they were well-known to gurus and pupils at the time of composition of the text? Did revisions/insertions during the course of transmission cause the ambiguity (deliberately or accidentally)? Is the text

kṣobhayed athavā mantrī gajahastākhyamudrayā $\|$ adhomukham dakṣapāṇịn nidhāyāṅgușthake same | nị̣kșiped añgulīh sarvā gajatunḍākrtir yathā || gajahastā mahāmudrā kathitā siddhidāyikā $\mid$. 
ambiguous because of the uncertainty of its redactors, i.e. they were rephrasing old teachings but were not sure of the details? Is this ambiguity the result of the redactors' diffidence in expressing secret teachings on sexuality? Could this ambiguity be seen as indicative of some major change in the tradition?

The first possibility, namely that the text is ambiguous deliberately, would imply that the author(s) or redactor(s) wanted to hide their secret teaching from unauthorised eyes. This is possible but not as typical as one would think. For instance, while they are difficult for the modern reader to decipher, the BraYā's radical teachings on sexual ritual are relatively straightforward concerning what is real and what is imaginary, and while there are technical terms which are not openly discussed in the text, ${ }^{50}$ and its language is far from being standard Pāninian Sanskrit, it is generally possible to understand how sexual rituals were supposed to be performed.

The next possibility hinted at above, i.e. the effect of bad writing, is possible, but the MaSam is far from being a very cryptic or confused text. It would have required minimal effort and ability on behalf of the redactors to clarify details that we miss: a few lines on how to acquire or invite a Māyā woman, similar to the BraYā's instructions on finding a partner, ${ }^{51}$ a verse on her role and position during the ritual, or a clear remark stipulating the yogin's solitude would have been enough.

On the other hand, one should not forget that texts like the MaSam were definitely not written with an outsider reader in mind who would try to understand them several hundred years later. Essential details could have been left out because they were obvious to the redactors.

As regards possible revisions and insertions, there are signs that MaSam 40 is made up of at least three distinct parts. Verses 40.1-28 constitute a small chapter in themselves with weak links to the rest of the chapter. What they have in common is the mention of "Kaula conduct" and bodily fluids. 40.29-37 and the rest of the chapter are more closely related. Both mention and discuss sexual rituals, but the first section, while mentioning sex with Yoginis, is silent on Māyā, the focus of the second part, i.e. verses 40.38-69, which seem as if they were an alternative and additional teaching. But this additional section may again be made up of passages drawn from various sources. The visualisation of Kāmeśvara and his partner (40.46cd-6oab) may come from a source different from that of the instructions on the sexual act itself, and this in itself would provide some explanation for discrepancies in the text. The text may

50 E.g. the term avagraha ("restraint") or pițha ("external genital organ of the female partner"). See Kiss 2015, 49, 47-48.

$5^{1}$ See BraYā 45.185cd-189ab. 
have originally described a sexual ritual with a human partner, but during the transmission of the text some passages teaching new ideas (such as a visualised partner) were inserted, thus making the text ambiguous.

This may lead us to another possibility, namely that at some point the redactors of the text became uncertain of the exact details of the ritual and when they tried to solve the problem they may have ended up obscuring it even further. Finally, the possibility of diffidence may also have played some role, especially if the female partner was meant to be purely imaginary, but other details of the ritual were not.

It seems that a wider perspective may be required to see what this chapter of the MaSam signifies. The ambiguity between actual sex and visualisation in chapter 40 may have its roots in the tension between sexuality and asceticism which is clearly manifest in the frame story of the text (chapters 1 and 55). The frame story contains a unique version of the legend of Matsyendra and Gorakșa: Matsyendra occupies the body of a dead king and indulges in sensual pleasures. It is Gorakșa, his disciple, who "rescues" Matsyendra from the trap of sexuality and power, and leads him back to an ascetic life. ${ }^{52}$ Taking into account this wider context, it is possible to discover the same tension in the teaching of MaSam 40 between a sexual ritual that may have originated in an earlier tantric strata of the cult, and its probably later hathayogic layers.

As I suggest elsewhere, ${ }^{53}$ the MaSam could provide clues about the transition of a tantric cult from Kaula practices, often involving transgressive elements, to early Hathayoga, often associated with brahmacārin practitioners. The text may be echoing or quoting old tantric texts with such descriptions of sexual rituals that aim at obtaining sexual fluids, but the redactors of the MaSam were perhaps in a transition towards more ascetic or brahmacary $\bar{a}-$ oriented teachings, and as a result, they come up with a fairly obscure variant of the figure of the tantric Yoginī: Māyā, first described as only a phantom, resembles the wholly mental visualisation of goddesses, but at the same time takes part in a human sexual ritual. The redactors may have had reservations about a sexual ritual with a low-caste woman, and tried to conceal this with instructions on visualisation to such an extent that even the presence of a human partner is now doubtful. They may also have had kundalinı in their thoughts: the

$5^{2}$ See Kiss 2009, 222-233 and 317-321.

53 Kiss 2009, 9: “[...] the MaSam provides some clues for, among other things, the understanding of the transition from the early Indian yoga traditions (Pātañjala and Śaiva) to the late and fully developed hațha-yogic teachings as well as of the transition from the early Kula traditions to the later Kaula teachings associated with the figure of Matsyendra." 
text as it stands now could be a metaphor for meditation on her. The manner in which they reconcile two (or three) attitudes, in this case those of explicit sexuality and of brahmacārin yogins' mental worship of a goddess (or of kuṇdalinī), is, as so often in tantric texts, less than convincing. But this imperfection, this ambiguity, is exactly the feature which seems to tell us something about the history of the cult, its transition from one phase to another.

\section{Acknowledgements}

I would like to thank Judit Törzsök, Dominic Goodall, Harunaga Isaacson and Gergely Hidas for their constant help and support. I am especially grateful to Shaman Hatley and Gergely Hidas for reading and commenting on a draft of this article.

\section{References}

\section{Primary Sources \\ Upanișads}

Patrick Olivelle, trans. Oxford World's Classics. Oxford: Oxford University Press, 1996.

\section{Kāmasūtra}

Srī Gosvamī Dāmodar Shastri, ed. The Kāmasūtra by Srī Vātsyāyana Muni. With the Commentary Jayamangala Of Yashodhar. Kāshi Sanskrit Series, no. 29. Benares: Chowkhamba, 1929 .

\section{Kubjikāmata}

T. Goudriaan and J. Schoterman, eds. Kubjikāmatatantra. The Kulālikāmnāya version. Leiden: E.J. Brill, 1988.

\section{Kaulāvalīnirnaya}

Arthur Avalon, ed. Calcutta: Sanskrit Press Depository, 1928.

\section{Khecarīvidyā}

See Mallinson 2007.

\section{Tantrāloka}

Madhusūdan Kaul Śāstrī, ed. Tantrāloka of Abhinavagupta with commentary (-viveka) of Rājānaka Jayaratha. Ksts nos. 23, 28, 30, 35, 29, 41, 47, 59, 52, 57 and 58. Bombay and Srinagar, 1918-1938. 


\section{Nityāṣoḍáikārṇava/Vāmakeśvarìmata}

Madhusūdan Kaul Śāstrī, ed. Vāmakeśvarīmatam, with the commentary Rājanaka Jayaratha. Kashmir Series of Texts and Studies, no. 66. 1945.

\section{Nityotsava of Umānandanātha}

A. Mahadeva Sastri, ed. Baroda: Oriental Institute, 1948.

\section{Pāśupatasūtra}

Pāśupatasūtram. Śrimaharșikauṇdinyakrtabhāsyopetam. Śrīmādhavānandagranthamālā, no. 1o. Varanasi: Shri Krishnananda Sagar, 1987.

\section{Bṛhadāraṇyaka-upanișad}

Nārāyaṇ Rām Ācārya, ed. İśādiviṃśottaraśatopaniṣadah. A Compilation of Well-Known 120 Upanisads. Bombay: Nirṇay-sāgar, 1948.

\section{Brahmayāmala}

National Archives Kathmandu, ms. no. 3-37o.

See Hatley 2007; 2018.

See Kiss 2015.

\section{Matsyendrasaṃhitā}

See Kiss 2009; 2020 (forthcoming).

(Ja) Maharaja Man Singh Library, Jodhpur (MMSL), No. 1784.

(Jb) No. 1783 , MMSL.

(Jc) No. 1782, MMSL.

(Jd) No. 1785, MMSL (not available for chapter 40).

(Well) $\beta$ 1115, Wellcome Library for the History and Understanding of Medicine, London.

\section{Rauravāgama}

3 vols. N.R. Bhatt, ed. Pondichéry: Institute Français d' Indologie, 1985-1988.

\section{Secondary Sources}

Biernacki, Loriliai. 2007. Renowned Goddess of Desire: Women, Sex, and Speech in Tantra. New York and Oxford: Oxford University Press.

Bunce, Frederick W. 1997. A Dictionary of Buddhist and Hindu Iconography. New Delhi: D.K. Printworld Ltd.

Dupuche, John R. 2003. Abhinavagupta: The Kula Ritual, as Elaborated in Chapter 29 of the Tantrāloka. Delhi: Motilal Banarsidass Publishers.

Hara, Minoru. 1966. "Materials for the study of Pāśupata Śaivism." Ph.D. thesis, Harvard University. 
Hatley, Shaman. 2007. “The Brahmayāmalatantra and Early Śaiva Cult of Yoginīs.” Ph.D. thesis, the University of Pennsylvania.

Hatley, Shaman. 2018. The Brahmayāmalatantra or Picumata. Volume I. Chapters 1-2, 39-40 \& 83. Revelation, Ritual and Material Culture in an Early Saiva Tantra. Collection Indologie, no. 133 (Early Tantra Series, no. 5). Institut Français d' Indologie/École française d'Extrême-Orient/Universität Hamburg.

Hume, Robert Ernest. 1921. The Thirteen Principal Upanishads. Oxford: Oxford University Press.

Kiss, Csaba. 2007. "Notes on the Matsyendrasamhitā." In Indian Languages and Texts through the Ages. Essays of Hungarian Indologists in Honour of Prof. Csaba Töttössy, edited by Csaba Dezső, 147-184. Delhi: Manoharlal.

Kiss, Csaba. 2009. "Matsyendranātha's Compendium (Matsyendrasaṃhitā): A Critical Edition and Annotated Translation of Matsyendrasamhita $1-13$ and 55 with Analysis." Ph.D. thesis, University of Oxford.

Kiss, Csaba. 2011. "The Matsyendrasaṃhitā: a Yogini-centered 13th-century Yoga text of the South Indian Sāmbhava Cult." In Yogi Heroes and Poets: Histories and Legends of the Nāths, edited by David Lorenzen and Adrián Muñoz, 143-162. Albany: State University of New York Press.

Kiss, Csaba. 2015. The Brahmayāmala Tantra or Picumata, Volume II. The Religious Observances and Sexual Rituals of the Tantric Practitioner: Chapters 3, 21, and 45. Collection Indologie, no. 130 (Early Tantra Series, no. 3). Pondichéry: Institut Français d'Indologie/École française d' Extrême-Orient/Universität Hamburg.

Kiss, Csaba. 2020 (forthcoming). The Yoga of the Matsyendrasamhitā. A Critical Edition and Annotated Translation of Matsyendrasamhitā 1-13 and 55. Pondichéry: Institut Français d'Indologie/École française d'Extrême-Orient.

Mallinson, James. 2007. The Khecarīvidyā of Ādinātha. A Critical Edition and Annotated Translation of an Early Text of Hațhayoga. London; New York: Routledge.

Rao, T. Gopinath. 1914. Elements of Hindu Iconography. 2 vols. (4 parts). Madras: Law Printing House, 1914-1916.

Sanderson, Alexis. 1988. "Śaivism and the Tantric Traditions." In The World's Religions, edited by S. Sutherland, L. Houlden, P. Clarke and F. Hardy, 66o-704. London: Routledge and Kegan Paul.

Sanderson, Alexis. 2002. "Remarks on the Text of the Kubjikāmatatantra." In IndoIranian Journal 45: 1-24.

Sanderson, Alexis. 2007. "Atharvavedins in Tantric Territory: The Ängirasakalpa Texts of the Oriya Paippalaadins and their Connection with the Trika and the Kālikula, with Critical Editions of the Parājapavidhi, the Parāmantravidhi, and the *Bhadrakātimantravidhiprakaraṇa." In The Atharvaveda and its Paippalāda Śākhā: Historical and Philological Papers on a Vedic Tradition, edited by Arlo Griffiths and Annette Schmiedchen, 195-311. Geisteskultur Indiens: Texte und Studien, no. 11; Indologica Halensis. Aachen: Shaker Verlag. 
Sanderson, Alexis. 2009. "The Śaiva Age:The Rise and Dominance of Śaivism during the Early Medieval Period." In Genesis and Development of Tantrism, edited by Shingo Einoo, 41-35o. Institute of Oriental Culture Special Series, no. 23. Tokyo: Institute of Oriental Culture, University of Tokyo, 20o9.

Sanderson, Alexis. 2014. “The Śaiva Literature." Journal of Indological Studies (Kyoto) 24-25 (2012-2013): 1-113.

Tāntrikābhidhānakośa. Dictionnaire des termes techniques de la littérature hindoue tantrique. Vol. 1. H. Brunner, G. Oberhammer et A. Padoux, eds. Österreichische Akademie der Wissenschaften, Philosophisch-historische Klasse, Sitzungsberichte, Bd. 681. Beiträge zur Kultur- und Geistesgeschichte Asiens Nr. 35. Vienna: Austrian Academy of Sciences Press, 2000.

White, David Gordon, ed. 20oo. Tantra in Practice. Princeton; Oxford: Princeton University Press.

White, David Gordon. 2003. Kiss of The Yogini: "Tantric Sex" in its South Asian contexts. Chicago; London: The University of Chicago Press. 